\title{
PD- 3
}

\section{高次元医用画像を用いた画像診断および手術支援システムとその将来}

東京慈恵会医科大学高次元医用画像工学研究所 鈴木直樹

マルチスライスCTを例に挙げるまでもなくCT、MRIの性能向上、高速化に 伴い、生体内の構造的機能的情報を三次元な情報として取得できる時代がやっ てきた。これにより無侵襲的に得た生体の画像情報を今までのように「読む」 のではなくて、直観的に「見える」情報に変換して活用しょうと言う流れが生 まれた。このためには得たデータをコンピュータグラフィクス技術を用いて三 次元像として再構筑することとなる。さらにまた高速に三次元画像を生成する ことにより、人体の動的な変化を観察、解析したり、その場で対象物に操作を 加えたりできるような医用四次元画像技術も臨床現場で使用可能となりつつあ る。これにより、より自由にかつ定量的に患者体内の多様な情報を得て診断、 治療に用いることができるようになった。さらに医用画像情報の高次元化（三 次元化、四次元化）は単に患者の体内を詳しく「見る」でなく、さらに新たな 利用法がある。それは医用高次元画像とバーチャルリアリティ（VR）技術の 結合により実現される。大量な情報を人間の直観に結びつけ、迅速かつ正確な 判断をさせるための手段として生まれたVR技術は生体内の複雑な現象の診断 や解析をよりし易くする武器となった。患者の体内に入りこんで診断したり (virtual endoscopy)、実際の手術に先立って仮想空間内で手術の予行演習を行 ったり（virtual surgery）することが現実のものとなってきた。そしてもし必要 であれば、VRにより作り出される患者の三次元構造に対して現実世界と同じ ように触わりながら手術作業を行うこともできる。今まで医療現場でしか得る ことのできなかった「経験」や「体験」を画像情報のみから得ることも、また それらをデジタルデータとして蓄積することも可能となったわけである。医用 画像の高次元化の流れは、新しい画像診断法だけでなく新しい治療法、新しい 医学教育を生み出す原動力になるものと考元る。 